\title{
24. SEDIMENTARY STRUCTURES OF CARIBBEAN LEG 15 SEDIMENTS ${ }^{1}$
}

\author{
Florentin Maurrasse, Lamont-Doherty Geological Observatory of Columbia University, Palisades, New York
}

\section{INTRODUCTION}

The main sedimentary structures observed in sediment removed from Leg 15 sites in the Caribbean may be grouped in two main categories which are further subdivided as shown below.

Primary or Syngenetic Structures

1) Bedding and lamination

a) Simple-random internal arrangement

b) Graded

c) Intersected-cross-bedded and cross-laminated

2) Bioturbation

Secondary or Epigenetic Structures

1) Concretions

2) Deformations and Microfractures

A third category not considered in this study comprises various artifacts due to drilling disturbance, among which "drilling breccia" and "flow-in" features are the most common. The latter displays characteristically inverse V-shaped stretched layers extending downward along core edges.

\section{SYNGENETIC STRUCTURES}

\section{Bedding and Lamination}

Compositional layering and color variations (Figures 1, 2 , and 8 ) are the most striking characters of these structures. Their frequency and magnitude vary with depth and from site to site. Beds are units thicker than one centimeter, whereas laminae include the smaller units (Payne, 1942). Stratum or layer are general terms applied to both size units.

Simple bedding and lamination - The strata show no obvious internal arrangement other than that due to mottling. Unit boundaries may be sharp or gradational (Figures 1, 2, 5, and 8) and become more pronounced at deeper sites (e.g., Middle Miocene of Site 153). Zones of differential induration may also generate bedded structures in sediments otherwise apparently uniform (Earliest Miocene, Site 146; Earliest Eocene, Paleocene, and Late Cretaceous, Site 146; Early Eocene, Paleocene, and Late Cretaceous, Site 152). Other simple layers include volcanic ash and volcanogenic clay (Figure 5-1) present at all sites except Site 147, Cariaco Basin.

Graded bedding and lamination - These structures show orderly size distribution of the particulate elements. They are present only in the oldest sediments of predominantly hemipelagic facies of Sites 146 and 153 (Figures 3 and 4); the Campanian of Site 152, Core 22; and the SantonianConiacian of Site 150, Cores 9-10, especially in the

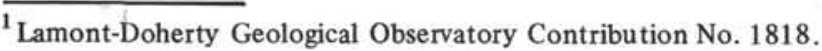

"hardground" immediately underlying volcanogenic clay in Core 10, Section 1. At Sites 146 and 153, graded layers occur with higher frequency and greater thickness in zones adjacent to the underlying diabase; their importance diminishes gradually upward as the facies becomes more typically eupelagic. However, xenoliths and interbedded metamorphosed sediments between diabases (Site 146, Core 41 , and Site 150, Core 11, Section 2) consist essentially of eupelagic packed foraminiferal limestone.

Cross-bedding and lamination (Figures 3 and 4) - Layers with intersecting internal structures generally cooccur with graded bedding and lamination at Sites 148 (Aves Ridge), 146 (Venezuela Basin), and 153 (Aruba Gap) (Tables 1A and 1B). They all occur in the oldest sediments, mostly of late Cretaceous age. Site 151 (Beata Ridge) shows similar structures only at the lithified horizon marking the boundary between early Cenozoic (early Paleocene) and late Cretaceous (Santonian).

In addition to the preceding structures, intermittent ungraded, sandy-textured layers occur throughout most of the Late Cretaceous of Sites 146 and 153 (Figures 2, 5, and 6). Comparable but less conspicuous foraminiferal layers also occur in younger Cenozoic sediments of Site 148 (Tables 1A and B). Radiolarian molds and well-preserved planktonic foraminifera make up the coarse fraction which is anomalously free of fine material and well sorted in contrast to the enclosing sediment.

\section{Bioturbation}

Structures related to burrow mottling (Sokolova, 1959; Ericson et al., 1961; Seilacher, 1967; Clark, 1968; Berger and Heath, 1968; Griggs et al., 1969; Donahue, 1971) are very widespread throughout most of the facies at all the sites. They become less conspicuous in brown clay facies (Late Miocene at Sites 149 and 150); and dark greenish gray clay facies (Pleistocene at Site 147; Late Miocene at Site 153; and Paleocene at Site 146, Cores 7 to 11). Mottling is enhanced when color layering is more pronounced (Figures 1, 2, 6, 7, and 8). Several types of burrows can be distinguished on the basis of their geometry:

Ellipsoidal burrows - These burrows have oblong and circular mottling with well defined or diffuse contours. Orientation is predominantly subhorizontal or parallel to the bedding plane. Of these, Simple burrows (Donahue, 1971) are mottling structures without internal structures other than those incidental to transecting tracks (Figures 1, 2,7 , and 8 ). Their size varies from less than $1 \mathrm{~mm}$ (Figure $8-1$ a) to over $30 \mathrm{~mm}$ (Figure 2 bottom 146-16-6, 8-26). Generally, as compaction increases with depth these burrows become more elliptical, spindle shaped, to lamina-like (Figures 5 and 10). Pseudo-halo burrows (Figures 2, 6, and 7) have an external contour similar to simple burrows but show off-center concentric layers of slightly different 
TABLE 1A

Summary of Structures Discussed in the Text

\begin{tabular}{|c|c|c|c|c|c|c|}
\hline $\begin{array}{c}\text { Rhythmic } \\
\text { Bedding }\end{array}$ & Lamination & $\begin{array}{c}\text { Graded } \\
\text { Bedding } \\
\text { Cross- } \\
\text { lamination }\end{array}$ & Bioturbation & Concretions & Microfracture & Breccia \\
\hline $149-15-1$ to 6 & $146-32-1$ & $146-7-1$ & $146-16-3$ & $146-10-2$ & $146-27-1$ & $148-28-1^{b}$ \\
\hline $149-16-1$ to 5 & $146-39-2$ & $146-23-2$ & $146-18-4$ & $146-27-1$ & $146-28-2$ to 3 & $150-10-1^{b}$ \\
\hline $149-17-4$ to 5 & $150-10-1$ & $146-31-1$ to 2 & $146-19-1$ to 2 & $146-32-2$ & $146-31-3$ & $151-11-\mathrm{b}^{\mathrm{b}}$ \\
\hline $149-20-2$ to 5 & $153-18-1$ & $146-32-1$ & $146-15-6$ & $148-12-6$ & $146-32-2$ & $153-12-1$ \\
\hline $149-21-5$ & $153-18-4$ & $146-33-1$ & $146-18-2$ & $148-13-5$ & $146-33-1$ & $153-12-3$ \\
\hline $147-12-4^{a}$ & & $146-34-1$ & $146-18-5$ & $148-14-4$ & $146-34-1$ & \\
\hline $147-12 \cdot 5^{a}$ & & $146-35-2$ & $146-24-1$ & $148-15-1$ & $146-35-1$ to 2 & \\
\hline $147-14-3^{a}$ & & $146-36-2$ & $146-25-2$ & $148-16-4$ & $146-36-2$ & \\
\hline $150-4-1^{a}$ & & $146-38-1$ & $146-27-1$ & $148-17-2^{a}$ & $146-38-1$ & \\
\hline $150-10-1^{\mathrm{a}}$ & & $146-39-2$ & $146-31-4$ & $148-18-1^{a}$ & $146-39-2$ & \\
\hline $150-20-2^{\mathrm{a}}$ & & $146-41-1$ & $146-32-2$ & $148-19-2$ & $146-41-1$ & \\
\hline $151-3-1$ to $4^{a}$ & & $148-4-4$ & $146-35-2$ & $148-20-3^{\mathrm{a}}$ & $148-28-1$ & \\
\hline $149-9-6^{\mathrm{a}}$ & & $148-28-1$ & $146-36-2$ & $148-24-2^{\mathrm{a}}$ & $152-16-1$ & \\
\hline $149-13-6^{a}$ & & $148-29-1$ & $146-39-2$ & $148-24-5^{\mathrm{a}}$ & $152-16-3$ & \\
\hline $149-19-3^{a}$ & & $150-10-1$ & $152-22-1$ to 2 & $148-25-1^{a}$ & $152-22-2$ & \\
\hline $149-23-3$ to 4 & & $153-16-2$ & $153-5-1$ to 3 & $148-27-1$ & $153-5-4$ & \\
\hline $153-4-1$ to 3 & & $153-18-1$ to 4 & $153-6-1$ & $150-4-2$ & $153-11-1$ to 3 & \\
\hline $146-16-4$ to 6 & & $153-19-1$ & $153-12-2$ & $150-4-3^{b}$ & $153-18-3$ & \\
\hline $146-17-3$ & & & $153-13-2$ to 3 & $150-5-4$ to $6^{b}$ & & \\
\hline $146-27-1$ & & & $153-14-1$ & $151-2-1$ & & \\
\hline $146-32-2$ & & & $153-16-2$ & $153-1-5$ & & \\
\hline & & & & $153-1-6$ & & \\
\hline & & & & $153-16-2$ & & \\
\hline & & & & $154-4-1$ & & \\
\hline
\end{tabular}

lithology unlike halo burrows described by Donahue (1971). Their presence is conspicuous in the late Cretaceous of Site 146.

Imbricate burrows - These are mostly elongated mottles characterized by an imbricated internal pattern composed of slightly different lithologies (Figures 2, 6, 8, and 9). Figures 2 and 6 show vertical burrows filled with meniscusshaped laminae, slightly concave upward. Unlike the "lateral stopping structures" of Hess, et al. (1971), the multiple cup-like laminae are mostly unidirectional and conform to the bedding plane. The "chevron burrow" of Figures 8 and 9 shows mottling with characteristic internal arrangement in a chevron pattern. These are similar to the imbricate burrows of Donahue (1971) and "Zoophycos Spreite" of Seilacher (1967). They are widespread in Late Cretaceous sediments (Table 1), but are scarce in younger sediments of Leg 15.

\section{EPIGENETIC STRUCTURES}

\section{Concretions}

Pyritic concretions occur frequently as aggregates of fecal pellets, pseudomorphs of burrow molds, and as coatings and filling material of foraminiferal tests. Crystalline pyrite (Figures 2 and 10) is better developed in the older sediments of Sites 146 and 153, especially in Core 16, Section 2 at the latter site. It is interesting to note that pyritic concretions are generally very abundant in greenish gray clay and marl facies of all sites, whereas they are practically nonexistent in the brown clay facies (Late Miocene of Sites 149 and 150). Hydrotroilite, an amorphous monosulfide of iron $\left(\mathrm{FeSH}_{2} \mathrm{O}\right)$, occurs as disseminated purplish blue blotches in soft sediments no blder than early Miocene.

Manganese-bearing nodules and micronodules occur only in the yellowish brown clay and marl facies of Sites 149 and 150 , both in the Venezuela Basin. Large-size nodules associated with volcanic debris are particularly well developed in Cores 4 and 5 of Site 150.

Copper-bearing concretions, apparently filling burrow tracks, are present in negligible amounts only in the dark green Paleocene clay facies of Site 146, Core 10, Section 2.

Calcite and calcitic veinlets are commonly found (Figures 3,9, and 10) in lithified Cretaceous sediments of Sites $146,150,152$, and 153 , and in the fractured diabases at Sites $146,150,151,152$, and 153 . 
TABLE 1B

Summary of Structures Discussed in the Text

\begin{tabular}{|c|c|c|c|}
\hline Chert & $\begin{array}{l}\text { Indurated } \\
\text { Beds } \\
\text { (not Lime- } \\
\text { stone) }\end{array}$ & $\begin{array}{c}\text { Volcanic } \\
\text { Ash or } \\
\text { Clay Layer }\end{array}$ & $\begin{array}{l}\text { Sandy } \\
\text { Textured } \\
\text { Layer }\end{array}$ \\
\hline $149-33-1$ & $146-2-5$ to 6 & $146-16-3$ to 4 & $146-17-5$ \\
\hline $149-42-4^{a}$ & $152-2-2$ & $146-16-6$ & $146-18-4$ \\
\hline $146-3 \mathrm{CC}$ & $152-2-4$ to 5 & $146-17-6$ & $146-18-6$ \\
\hline $146-4$ CC & $152-3-2$ to 3 & $146-18-3$ & $146-19-1$ \\
\hline $146-5 \mathrm{CC}$ & $152-3-5$ & $146-19-3$ & $146-19-2$ \\
\hline $146-6 C^{a} C^{a}$ & $152-6-5^{b}$ & $146-23-2$ to 3 & $146-20-2$ \\
\hline $146-20-1$ & $152-7-3^{b}$ & $146-29-1$ & $146-22-2$ \\
\hline $146-24-1$ & $152-7.4^{\mathrm{b}}$ & $146-35-2$ & $146-23-2$ \\
\hline $146-26-1$ & $152-8-1^{b}$ & $146-36-2$ & $146-26-1$ \\
\hline $146-26-2$ & $152-14-1^{b}$ & $146-38-1$ & $146-26-2$ \\
\hline $146-27-1^{a}$ & $152-15-2$ & $146-39-1$ & $146-27-1$ \\
\hline $146-27-2$ & $152-17-1$ & $146-39-2$ & $146-27-2$ \\
\hline $146-28-2$ & $152-18-2$ & $146-41-1$ & $146-28-1$ \\
\hline $146-28-3$ & & $148-3-4$ & $146-28-2$ \\
\hline $146-29-1$ & & $148-8-3$ & $146-29-1$ \\
\hline $146-30-1$ & & $148-8-4$ & $146-30-1$ to 4 \\
\hline $146-30-2$ & & $148-17-4$ & $146-31-1$ to 4 \\
\hline $146-30-4$ & & $148-27-6$ & $146-32-1$ \\
\hline $146-31-1^{a}$ & & $150-9-1$ & $146-32-2$ \\
\hline $146-31-2$ to 4 & & $150-10-1$ & $146-33-1$ \\
\hline $146-32-1$ to 2 & & $151-3-6$ & $146-34-1$ \\
\hline $146-33-1$ & & $151-10-1$ & $146-35-1$ \\
\hline $146-34-1$ & & $152-2-1$ & $146-35-2$ \\
\hline $146-35-1^{a}$ & & $152-2-2$ & $146-41-1$ \\
\hline $146-35-2$ & & $152-2-4$ & $148-2-1$ \\
\hline $146-38-1$ & & $152-9-1$ & $148-3-1$ \\
\hline $150-6-\mathrm{CC}$ & & $152-10-1$ & $148-4-4$ \\
\hline $150-8-\mathrm{CC}$ & & $152-16-2$ & $148-5-3$ \\
\hline $150 \mathrm{~A}-2-1$ & & $153-6-2$ & $148-10-2$ \\
\hline $152-2-2$ & & $153-15-3$ & $152-$ \\
\hline $152-3-5$ & & $153-16-1$ & $153-16-1$ \\
\hline $152-4-3$ & & $153-16-2$ & \\
\hline $152-15-2$ & & $149-18-4$ & \\
\hline $152-16-1$ & & $149-28-2$ & \\
\hline $152-16-2$ & & $149-28-3$ & \\
\hline $152-18-1$ & & $149-28-4$ & \\
\hline $152-21-1$ & & $149-29-1$ & \\
\hline $152-22-1^{a}$ & & $149-29-2$ & \\
\hline $153-8-1^{a}$ & & $149-32-3$ & \\
\hline $153-9-1$ & & & \\
\hline $153-9-2$ & & & \\
\hline $153-12-1$ & & & \\
\hline $153-12-3$ & & & \\
\hline $153-13-2^{a}$ & & & \\
\hline $153-14-1$ & & & \\
\hline $153-15-1$ & & & \\
\hline $153-15-2$ & & & \\
\hline $153-15-3^{\mathrm{a}}$ & & & \\
\hline $153-16-1$ & & & \\
\hline
\end{tabular}

${ }^{\mathrm{a}}$ Chert lens.

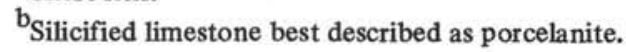

\section{Deformations and Microfractures}

Natural deformation structures are common in the highly compacted and lithified sediments of Late Cretaceous and Early Cenozoic age at Site 153 and in most of the Cretaceous limestones of Sites 146, 150, and 152. Subvertical cracks and microfractures (Figures 3, 4, 9, and $10)$, with minor relative displacement, permeate preexisting structures. Intensity of microfracturing depends on the degree of lithification of the sediments but is more intense and better developed at Site 153, particularly at the level of the Mesozoic-Cenozoic boundary (Figure 9). Best described as an "auto breccia" (see the sedimentology summary of Site 153 , this volume) this structure consists of heterometric fragments similar to, and different from, the main fractured rock. Fragments similar to the enclosing rock are angular and are harder and larger (up to $9 \mathrm{~mm}$ in length) than the softer chalk that makes up the smaller and more rounded dissimilar fragments (Figures 9-2). As in most of the net of dislocation microcrystalline and sparry calcite compose the cementing material well developed in Core 12 of Site 153.

Plastic deformation is evident at some levels (Figures 3-4) of the Cretaceous sediments of Sites 146 and 153, and slickensided surfaces occur at fracture planes in the marl of Site 152 (Core 22, Section 2) and Site 153 (Core 5, Section 4).

\section{ACKNOWLEDGMENTS}

I am grateful to James D. Hays for critically reading the manuscript and to Terence Edgar for helpful suggestions. Discussions with R. Bischke, Darlene Richardson, and P. H. Chen were also helpful. This work was partly supported by the Deep-Sea Drilling Project, and major financial support was provided through NSF grant No. GA 29460 and Office of Naval Research Contract N00014-67-0108-0004.

\section{REFERENCES}

Berger, W. H. and Heath, G. R., 1968. Vertical mixing in pelagic sediments: J. Marine Res., v. 26, No. 2, p. 134-143.

Clarke, R. H., 1968. Burrow frequency in abyssal sediments: Deep-sea Res., v. 15, p.397-400.

Donahue, J., 1971. Burrow morphologies in north-central Pacific sediments: Marine Geol., v. 11, p.M1-M7.

Ericson, D. B., Ewing, M., Wollin, G. and Heezen, B. C., 1961. Atlantic Deep-sea sediment cores: Geol. Soc. Am. Bull., v. 72, p. 139-286.

Griggs, G. B., Carey, A. G., Jr. and Kulm, L. D., 1969. Deep-sea sedimentation and sediment-fauna interaction in Cascadia channel and on Cascadia abyssal plain: Deep-sea Res., v. 16, p.157-170.

Hess, R., von Rad, U., and Fabricius, F. H., 1971. Holocene sedimentation in the strait of Oranto between the Adriatic and Ionian Seas (Mediterranean): Marine Geol., v. 10 , p. $293-355$.

Seilacher, A., 1967. Bathymetry of trace fossils: Marine Geol. v. 5, p. 413-428.

Sokolova, M. N., 1959. On the distribution of deep-water bottom animals in relation to their feeding habits and the character of sedimentation: Deep-sea Res., v. 6, p. $1-4$. 
149

$15-5 \& 16-5$

(1)
149

$38-2 \& 38-3$

(2)

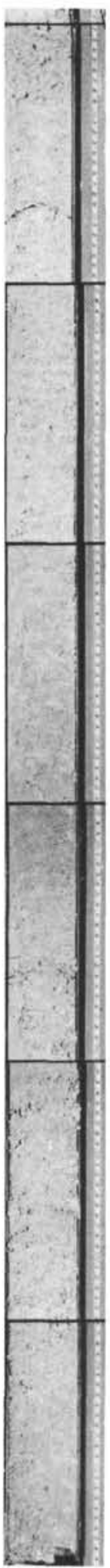

146

$15-6 \& 16-5$

(3)
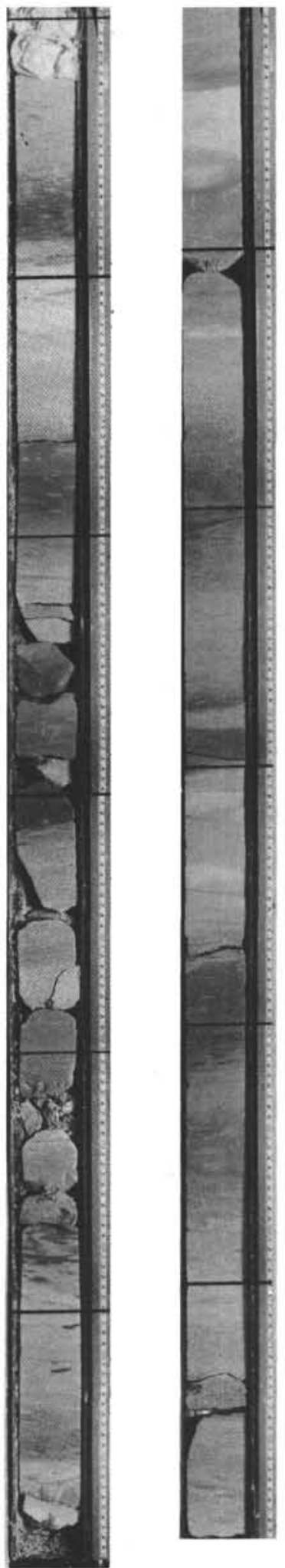

Figure 1. Typical examples of color and compositional layering at three stratigraphic levels in the combined Hole 146/149: (1) Middle Miocene, (2) Middle Eocene, (3) Upper Cretaceous Maestrichtian. 
NAT. SIZE

$146-16-6 / 8-26 \mathrm{~cm}$.

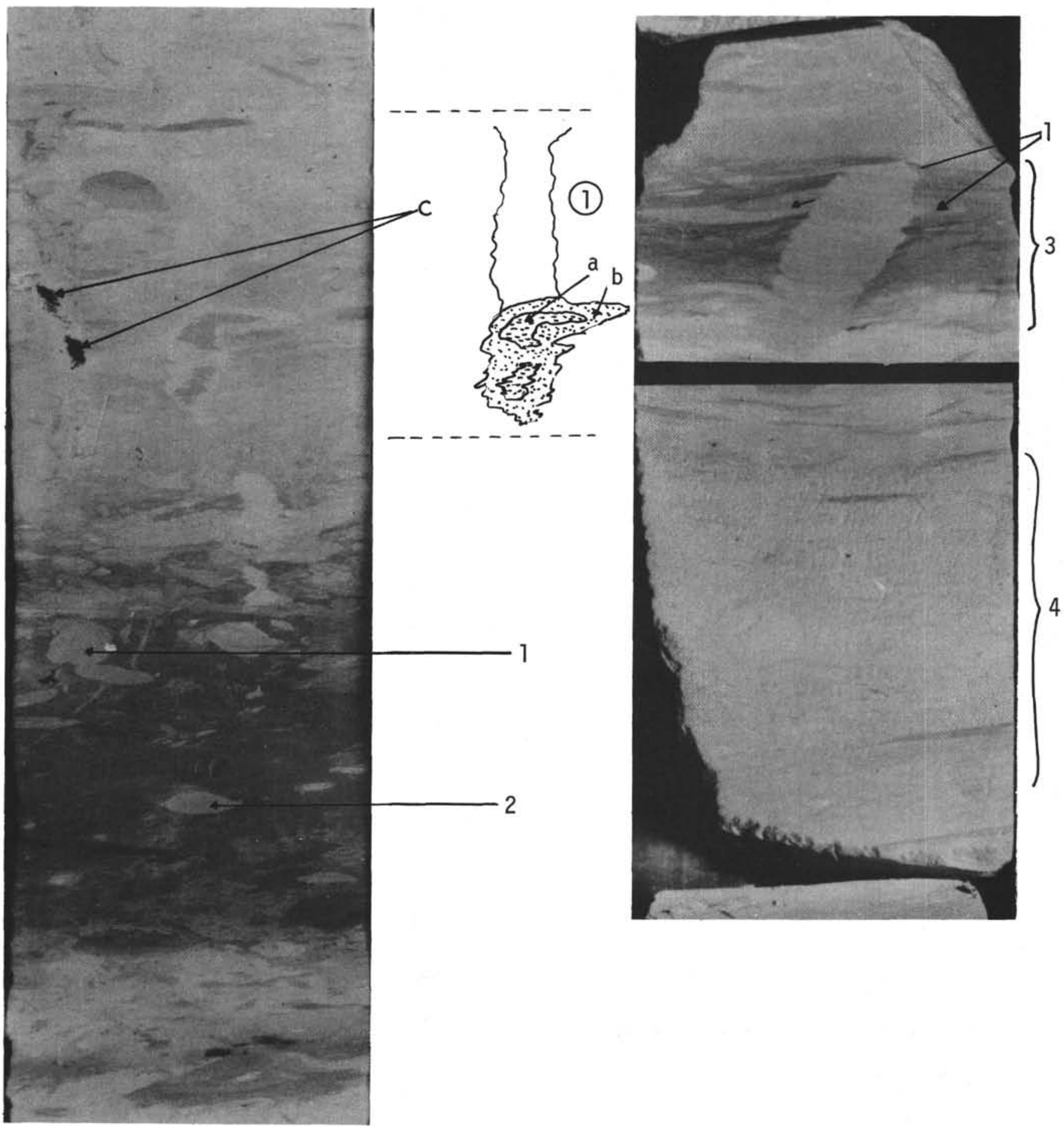

$146-27-1 / 70-83 \mathrm{~cm}$.

Figure 2. 1) Pseudo-halo burrow: (a) silty clay, (b) sparse biomicrite, (c) pyrite filling in vertical burrow; 2) simple burrow becoming somewhat spindle shaped due to compaction effect; 3) typical vertical imbricate burrow, here intersecting a flattened pseudo-halo burrow; 4) sandy textured layer with ill-defined bottom contact; (Note compositional layering with conspicuous color change). 
(1)

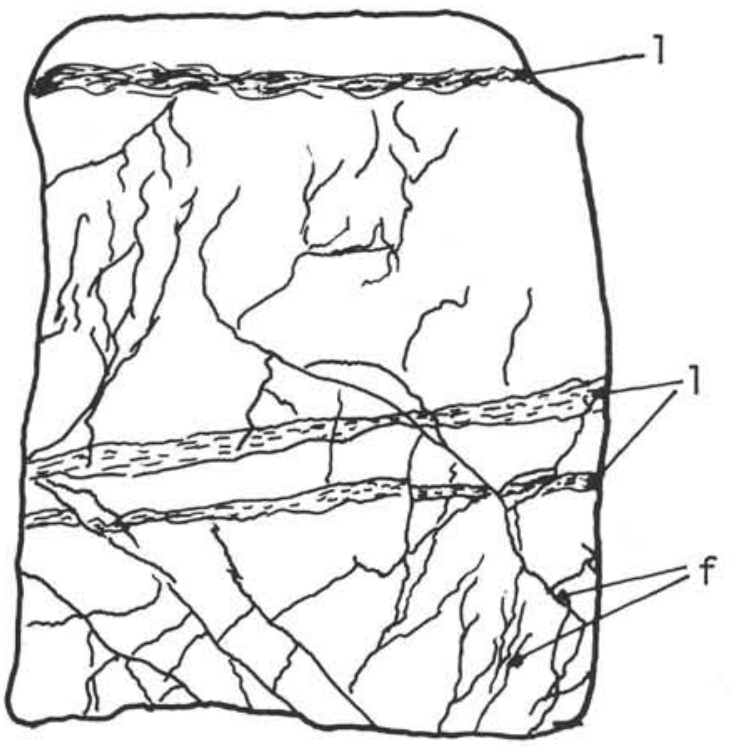

$146-36-2 / 94-101 \mathrm{~cm}$.

(2)

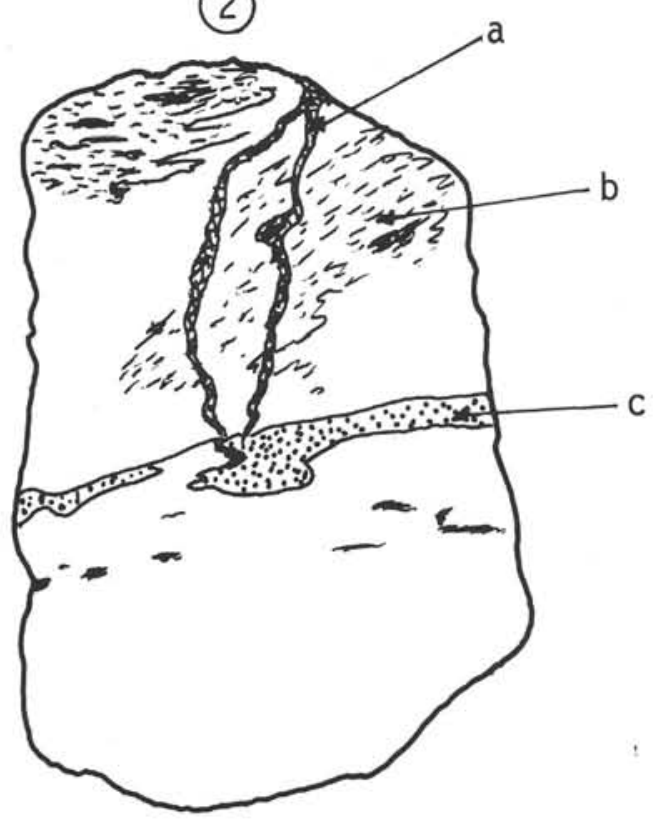

Figure 3. Various features of microfractures and associated calcitic veins: (a) Microcrystalline and sparry calcite veins (note bending of laminae around convoluted calcite vein in sample 4); (b) burrow mottling filled with clay containing plant debris and pyrite in sample 2, and filled with coarser detritus in sample 4'; (c) discontinuous fine-grained detrital layer in samples 2 and 3; (d) fine-grained detrital layers with sharp basal contact and graded bedding; (e) clay zone above graded bedded layer transected by simple burrows displaying coarser detritus; (f) microfractures (note stylolitic occurrence in sample 3); (g) clay laminae transected by net of microfractures in sample 1 . 


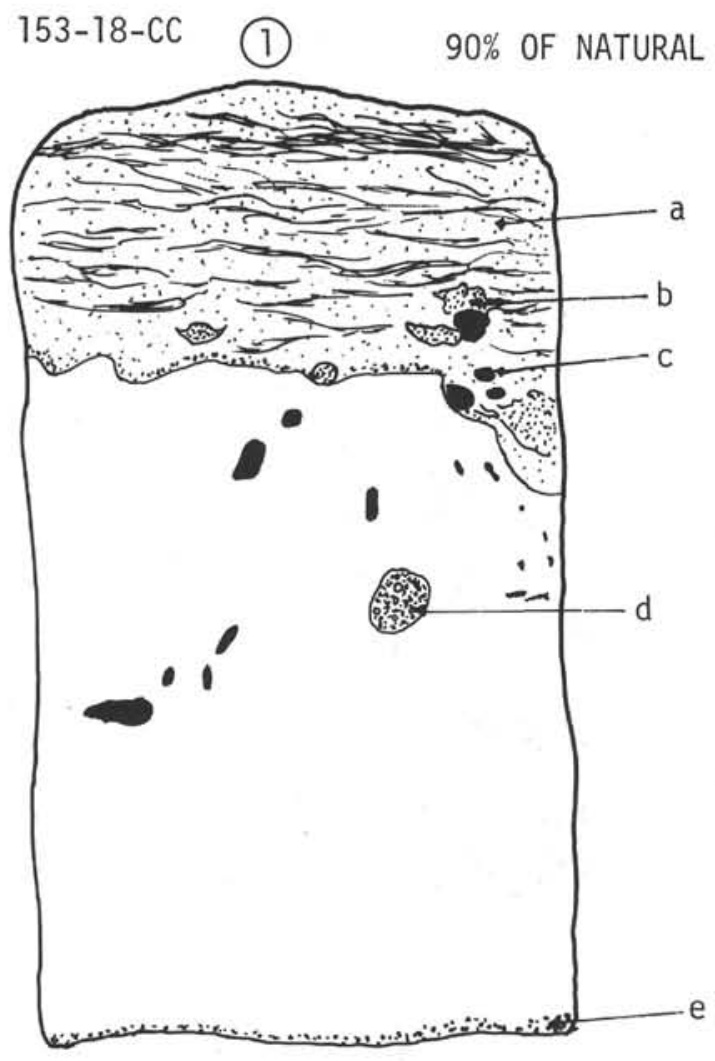

\section{SIZE}

(3) $146-39-2 / 62-84 \mathrm{~cm}$.

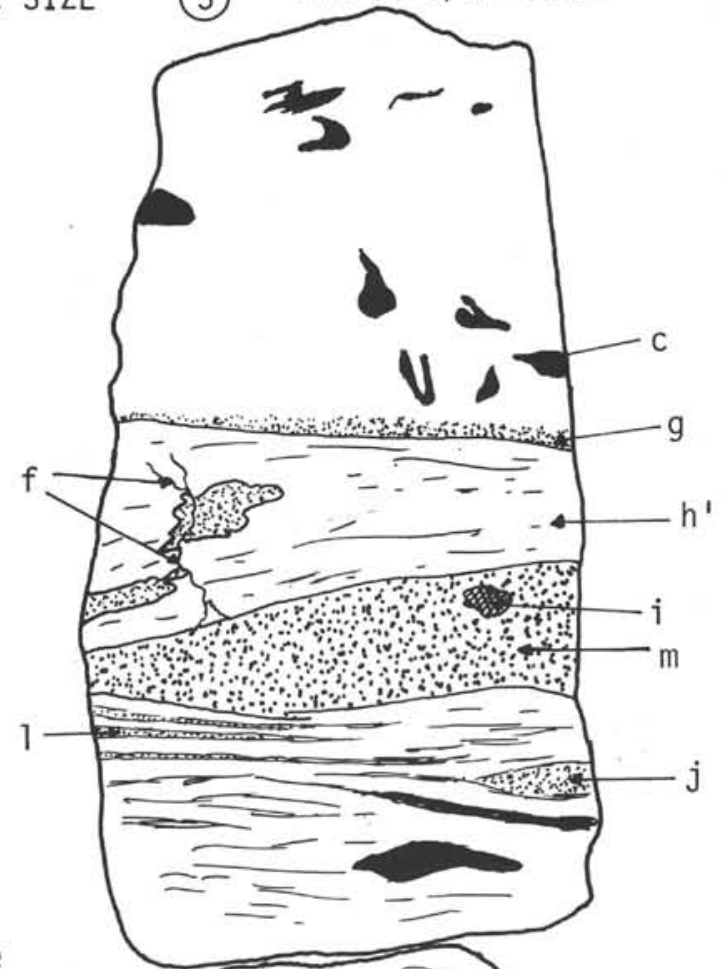

$146-32-2 / 91-101 \mathrm{~cm}$.

(3)

(2)
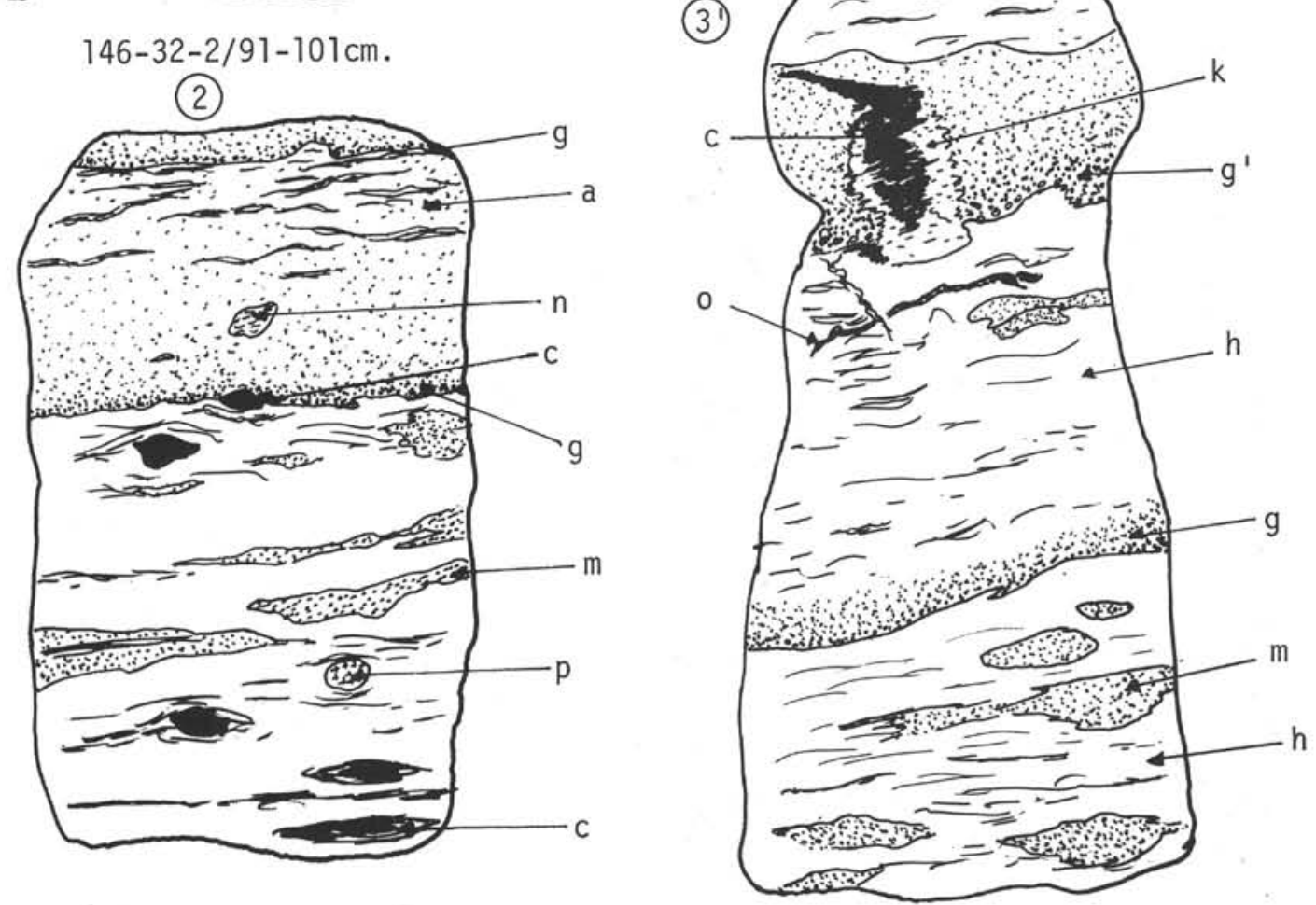

Figure 4. Various subaqueous flow structures, burrows, microfractures, and concretions at Sites 146 and 153: (a) intermixed fine-grained detritus and clay much more characteristic at top of graded layers; (b) coarser detrital lens, probably mold of simple burrow; (c) burrow filled with olive-black to dark greenish-gray clay; (d) medium-grained sand lens, coarser than surrounding and adjacent sand layers; (e) graded layer with lower part missing; (f) microfracture cutting across fissile clay (h) and sand lens; (g) graded bed with sharp basal contact (note undulating bottom structure in fragments 1, 2, and $\left.3^{\prime}\right)$; (h) predominantly clay and silty clay, fissile zone above coarser detritus in graded bed, except $h^{\prime}(3)$; (i) sparry calcite lens included in nongraded sandy layer; (j) sandy lens in fissile clay zone; (k) vertical burrow transecting graded layer; (1) sandy laminae in fissile clay zone; (m) irregular sand lens somewhat mixed with silt and clay; (n) simple burrow filled with clay similar to that found in (a); (o) calcite vein nearly parallel to bedding plane; ( $\mathrm{p}$ ) pyrite concretion. 
$146-16-4 / 75.5-84 \mathrm{~cm}$.

(1)

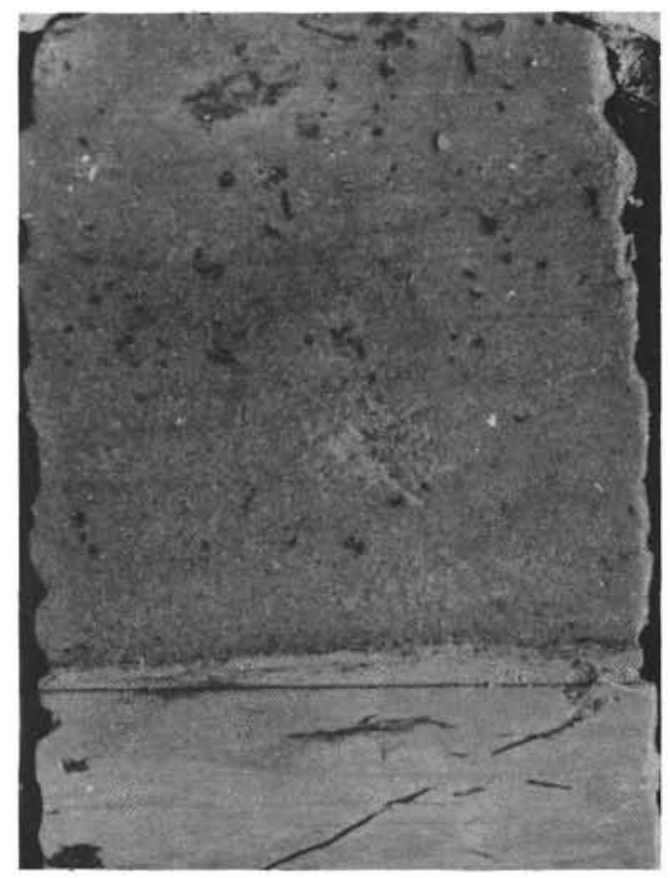

$146-32-2 / 55-62 \mathrm{~cm}$.

(2)

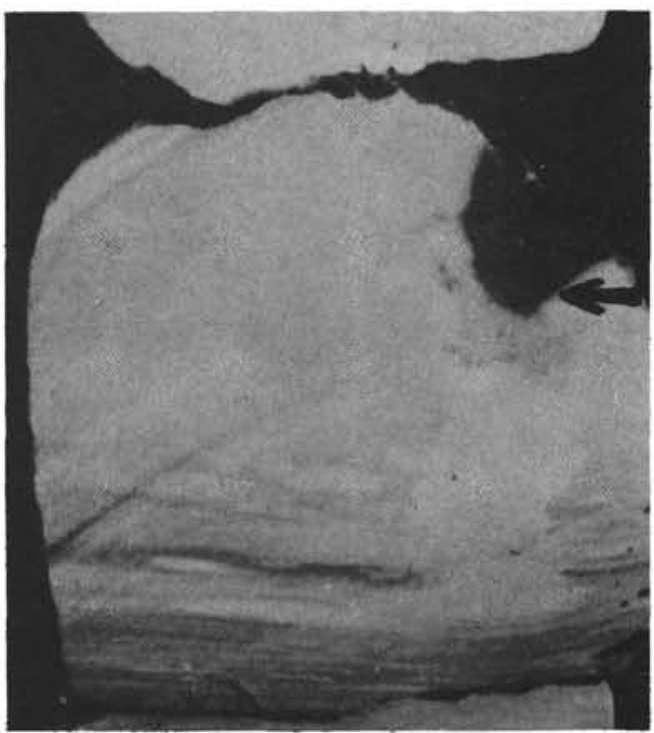

$146-31-1 / 129-135 \mathrm{~cm}$.

(3)

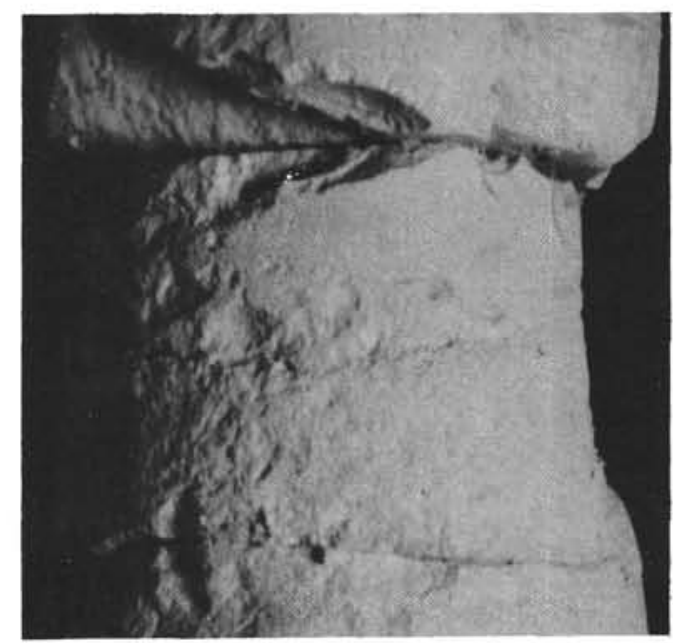

$146-19-1 / 56-63 \mathrm{~cm}$.

(4)

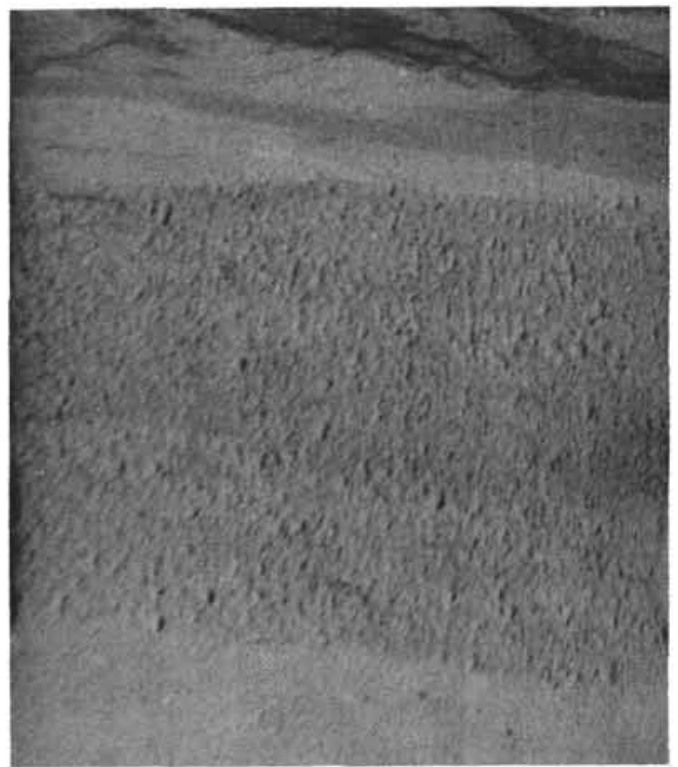

Figure 5: 1) Volcanogenic clay with sharp basal contact on eupelagic sparse foraminiferal nannoplankton chalks; 2) vertical burrow terminated by chart lense (arrow) in upper part. (Note bending due to differential compaction of sediment at lower part of vertical burrow in clay rich zone); 3) typical sandy. textured layer as seen from unsplit core; 4) same structure in another core. (Note pitted surface caused by transected hollow foraminifera tests). 


\section{NAT. SIZE}

$146-19-1 / 82-96 \mathrm{~cm}$.

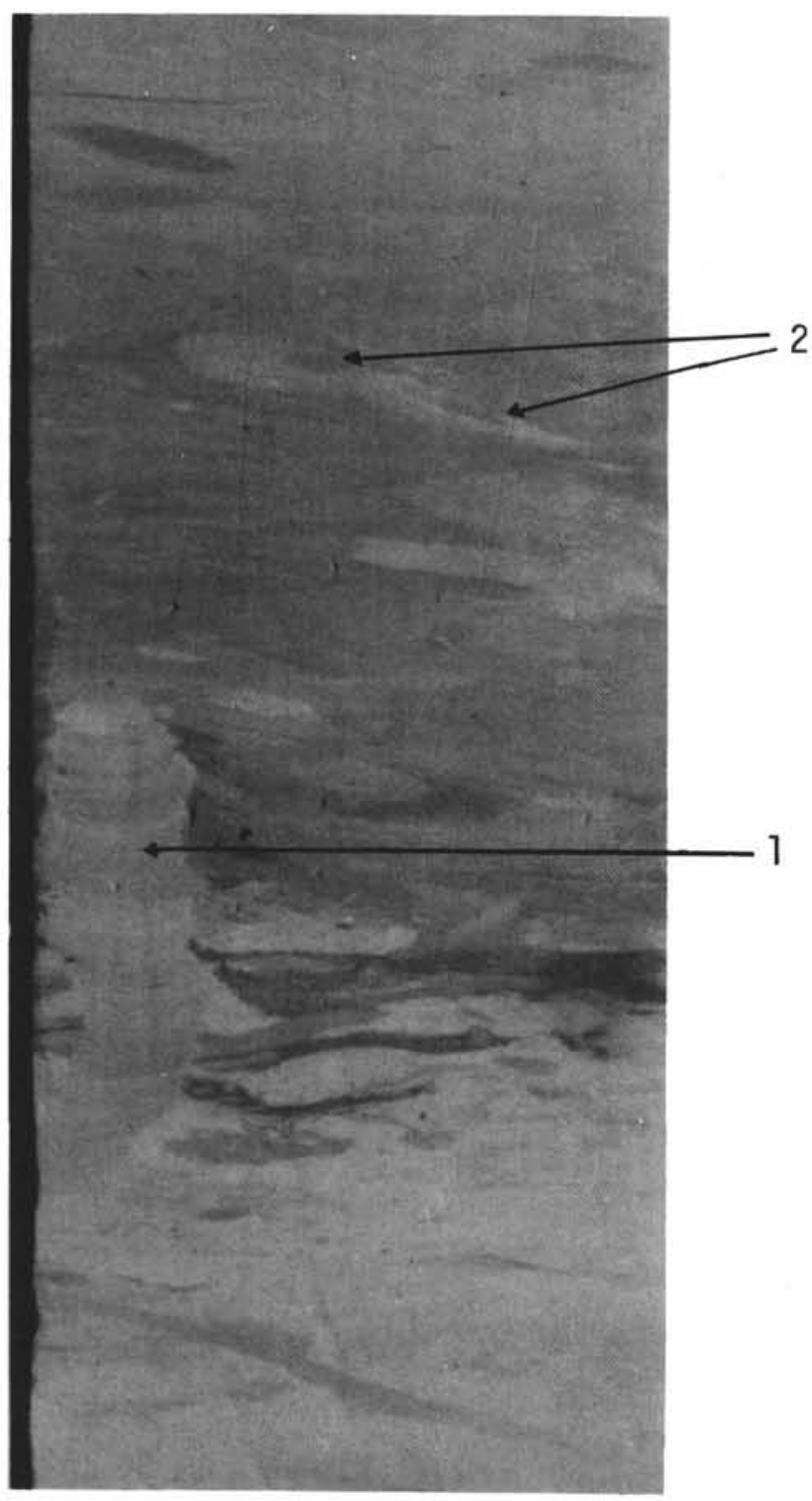

$146-19-2 / 16-30 \mathrm{~cm}$.

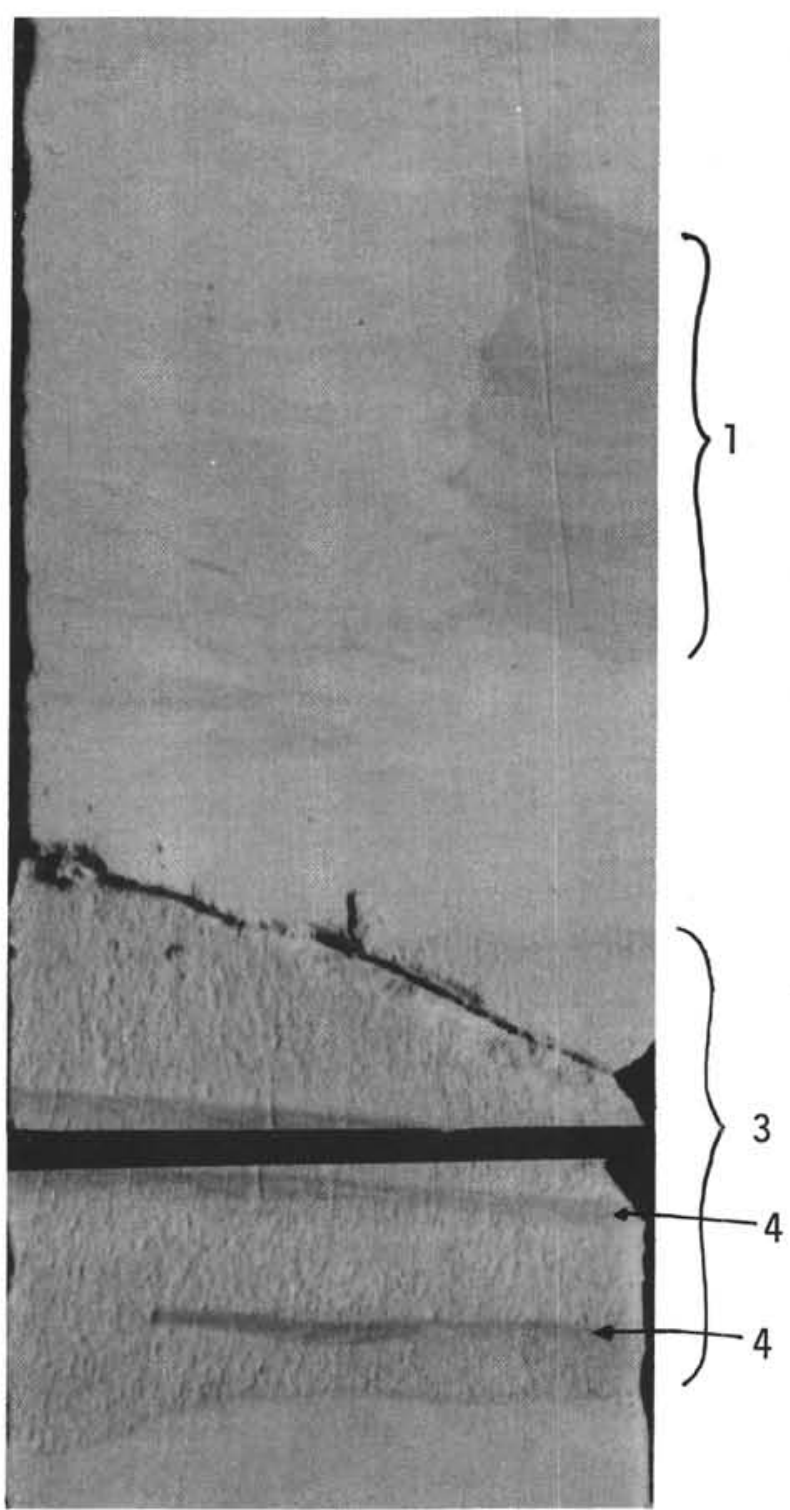

Figure 6: 1)Vertical imbricate burrow; 2) pseudo-halo burrow with typical off-centered internal structure; 3) typical sandy textured layer in Cretaceous sediments of Leg $15 ; 4)$ burrow mottling of chevron type. 

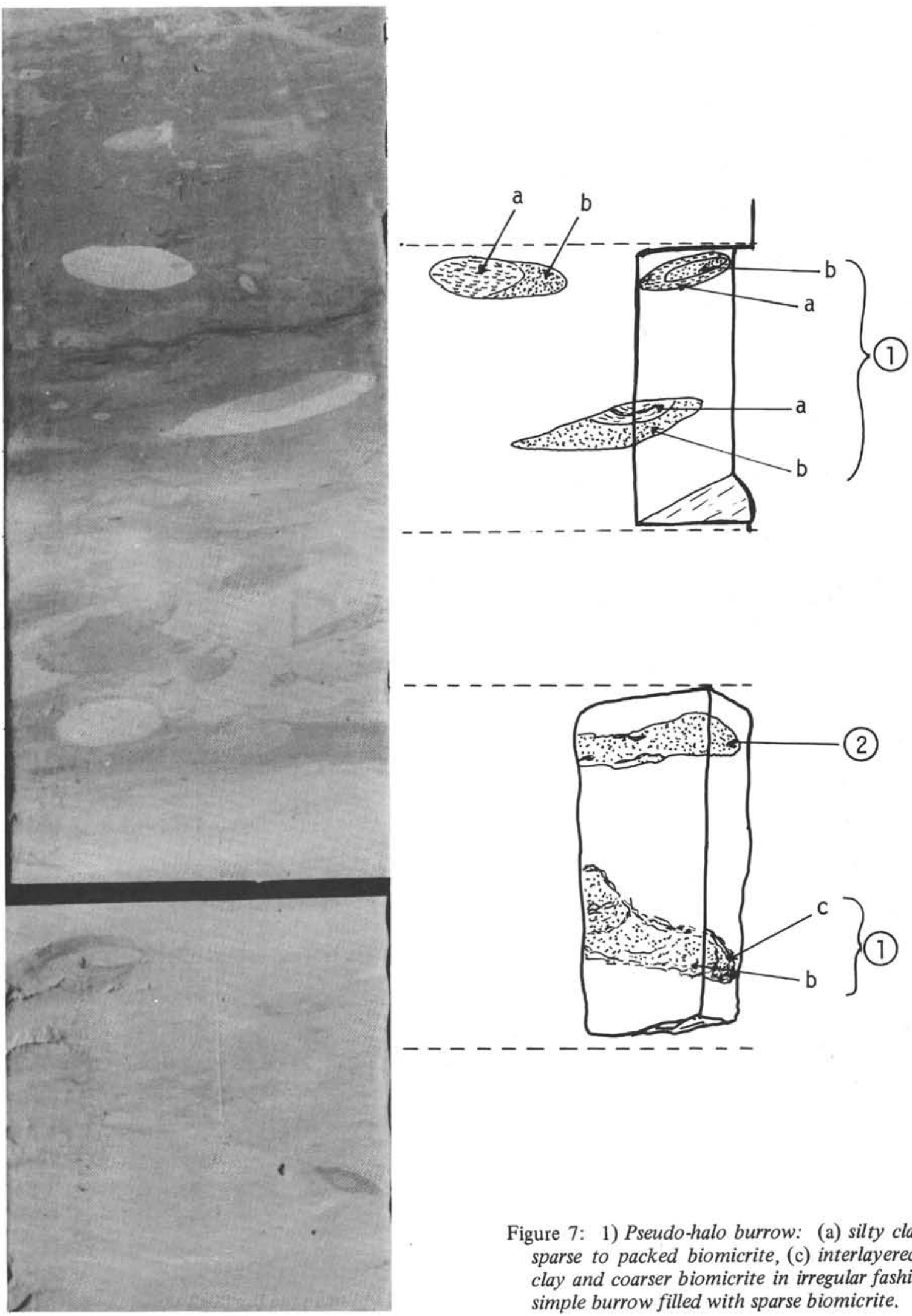

Figure 7: 1) Pseudo-halo burrow: (a) silty clay, (b) sparse to packed biomicrite, (c) interlayered silty clay and coarser biomicrite in irregular fashion; 2) simple burrow filled with sparse biomicrite. 
NAT. SIZE

$146-16-6 / 33 \cdot 5-48 \cdot 5 \mathrm{~cm}$.
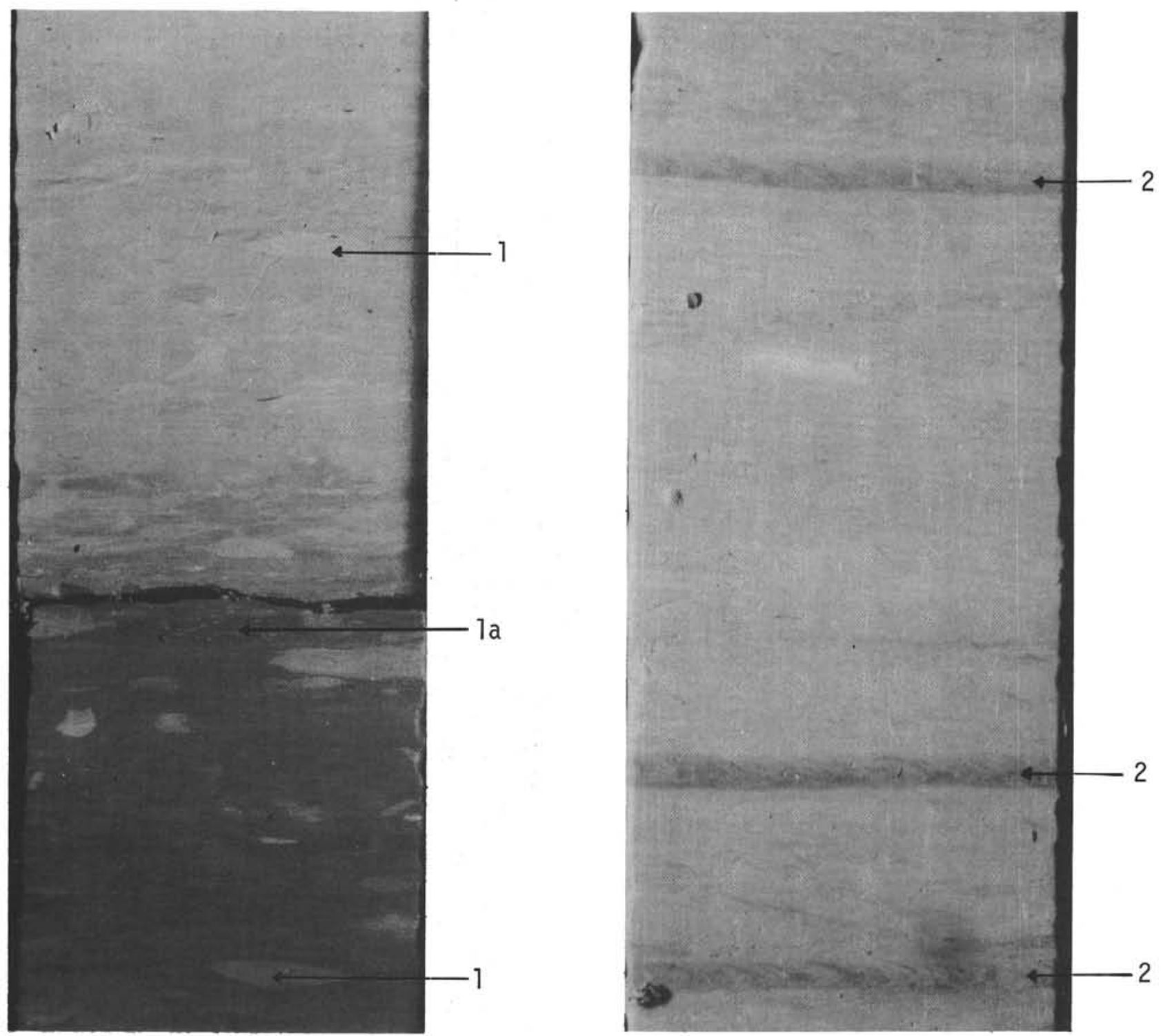

Figure 8: 1) Simple burrow of various sizes superimposed to color and compositional layering. (Note minute simple burrows transecting larger ones at 1a); 2) some typical examples of imbricate chevron type of burrows. 


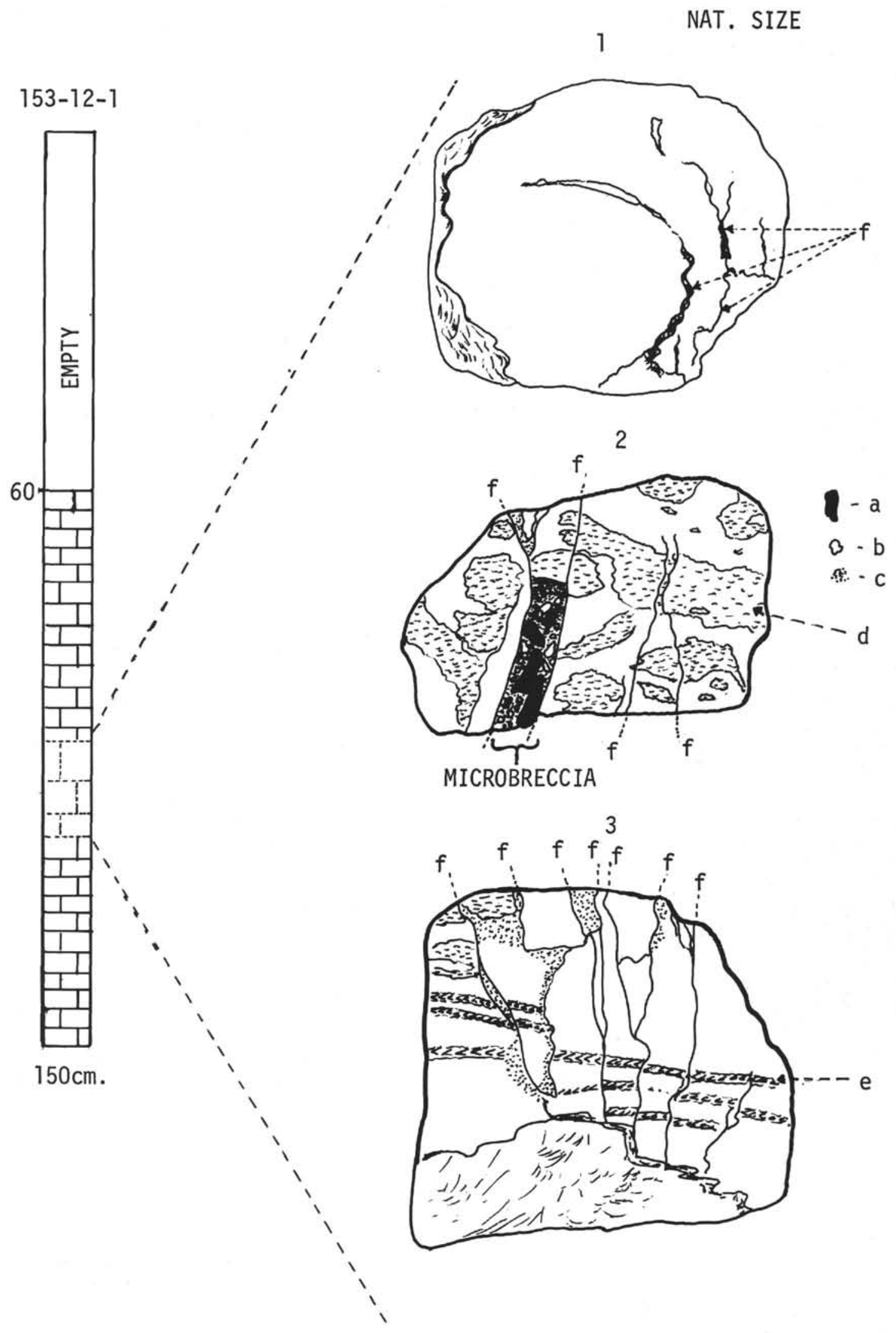

Figure 9. Loose fragments of tectonized limestone at Mesozoic-Genozoic stratigraphic boundary: (a) limestone fragments similar to enclosing rocks, (b) soft chalk fragments, (c) microcrystalline and sparry calcite filling fractur spaces normal and parallel to sheet plane, (d) burrow mottling of simple type, (e) burrow mottling of chevron type, (f) fractures. 


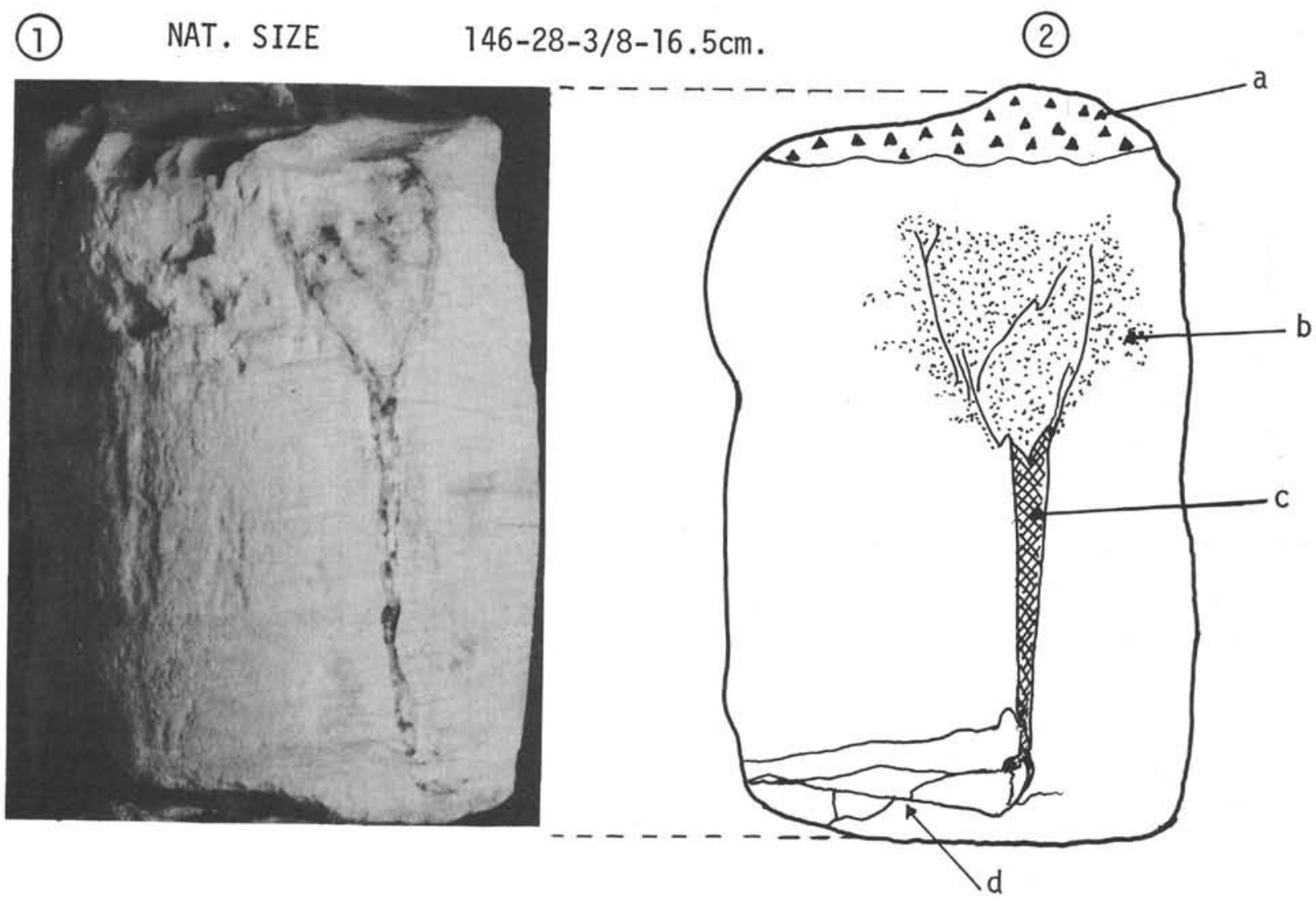

$146-27-1 / 6-13.5 \mathrm{~cm}$.
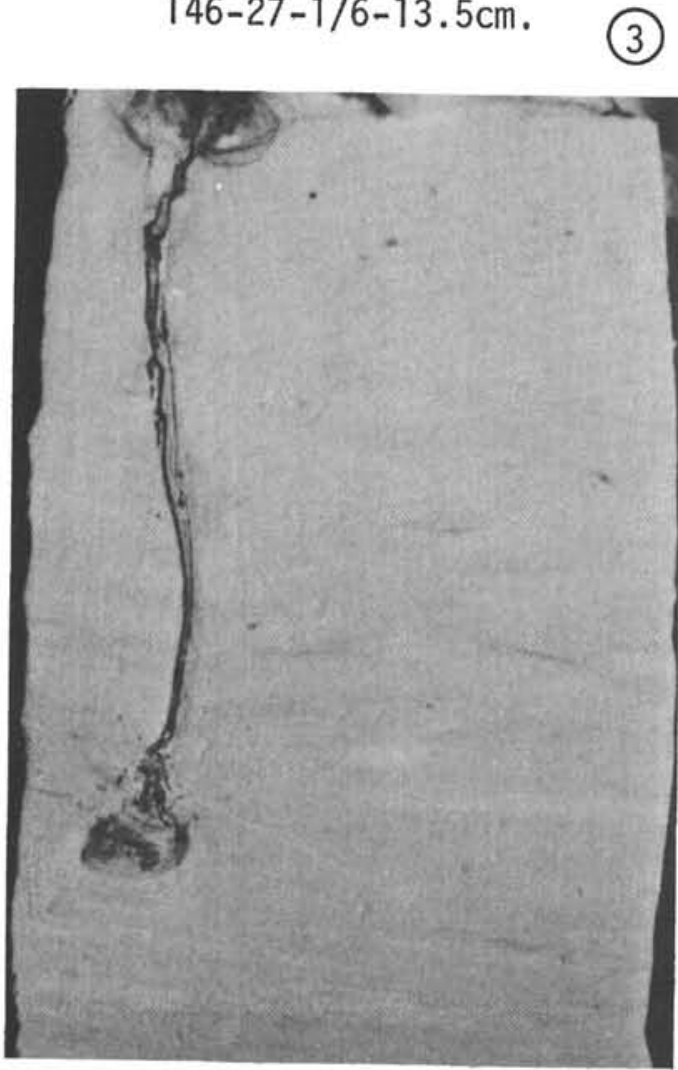

$146-27-1 / 90.5-99 \mathrm{~cm}$.
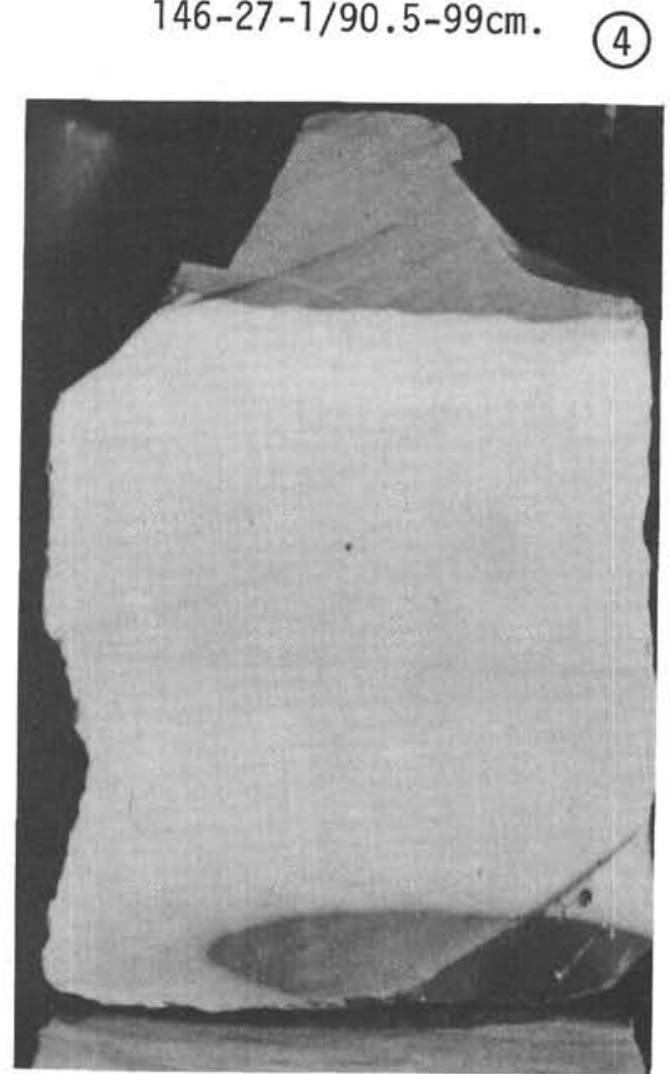

Figure 10: 1) and 2), are same net of microfractures in limestone, as seen from unsplit and split core respectively: (a) reddish brown chert with sharp undulating basal contact, (b) diffused pyrite in the vicinity of microfractures, (c) fracture filled with sparry calcite and crystalline pyrite as minute veinlet transecting or replacing calcite filling, (d) microfractures filled with cryptocrystalline calcite; 3) pyrite vein in sandy textured layer rich in radiolarian molds; 4) chert stringer and lense in limestone. 